\title{
THE USE OF ELLIPSIS IN HINGLISH SHORT MOVIE
}

\author{
Sinta Fitri SafwaRika ${ }^{1}$, Nai Supartini Atmawidjaja ${ }^{2}$ \\ ${ }^{1}$ IKIP Siliwangi \\ ${ }^{2}$ IKIP Siliwangi \\ ${ }^{1}$ sintafitrisafwarika1997@gmail.com, ${ }^{2}$ nai.supartini99@gmail.com
}

\begin{abstract}
In discourse features, including cohesion, there is an ellipsis. Ellipsis is one of the features to make communication more effective especially in written. Ellipsis exist in three kinds there are a nominal ellipsis, verbal ellipsis, and clausal ellipsis. Based on that problem, the researcher wants to investigate what are the ellipsis elements used, implemented and how are the ellipsis expressed in Hinglish Short Movie which have title "Divorce". In order that can give critical analyze, describe the ellipsis elements and the interpretation of the ellipsis in the dialogues of that movie itself and practically it gives contribution for the teachers, students, researcher, education and other researchers. The technique used by the researcher was documentation by watching "Divorce" Hinglish with analysis of the dialogues from the movie. From the data that have been analyzed, it was found that there were three types of ellipsis elements that occurred in the analysis of ellipsis in "Divorce" Hinglish Movie. The most frequent types were verbal ellipsis occurred 3 times clausal and nominal ellipsis occurred once of a time both of them. Verbal ellipsis was the most productive types.
\end{abstract}

Keywords: Discourse, Cohesion, Ellipsis, Nominal Ellipsis, Verbal Ellipsis, Clausal Ellipsis

\section{INTRODUCTION}

In every natural communication exactly will always use about discourse features including Cohesion, Cohesion refers to linguistic devices like references, conjunctions, substitution, and ellipsis, which give texture and unity to spoken and written texts (Tajeddin \& Rahimi, 2017). The use of cohesive devices enhances concreteness and terseness of meaning exchange and negotiation and makes comprehensibility and interpretation of discourse easier (Tajeddin \& Rahimi, 2017). Spoken and written discourses showed the conection between gramatical individual clauses and utterances. One of these grammatical links is an ellipsis.

Ellipsis is relation between words, groups and clauses as distinc from refrence which is a relation between meanings. Ellipsis can be familiar nations that is "something left unsaid" (Sholeh, 2014) . Obviously, the use of ellipsis will help to develop natural communication. In view in this function natural communication is the daily activity for human being, every people in their life will do communication especially about conversation, in conversation sometimes we need the simplest way to deliver intention and meaning, here ellipsis is the omission from speech or writing of a word or words that are superfluous or can be understood from contextual clues. Although the use of ellipsis in conversation effective or not, because it depends on the speaker when they use ellipsis and the listener can interpret the purpose. Ellipsis is broken down into nominal, verbal and clausal .

Firstly we have nominal ellipsis, nominal ellipsis is often involves omission of a noun headword, for example: Nelly liked the green tiles, I preferred the blue. For this type of the sentence, it is as nominal ellipsis because the word "tiles" involves omission of noun headword (Lewis, 2017). 
Secondly is Verbal ellipsis refers to ellipsis within the verbal group where the previous verbal group is presupposed by an elliptical verbal group Example: She takes the little one suitcase, his father the biggest. For this type of the sentence, it is as verbal ellipsis because omission an element from the verbal group of the word "takes". (DEDDY PERDANA BAKTI, 2017)

Clausal ellipsis, the clause is the point of departure and presupposes any clause in a complex together with all clauses contingent on it and usually Clausal ellipsis involves a clause elements may be omitted especially common are subject-pronoun omissions (doesn't matter, hope so, sorry, can't help you, etc) and Ellipsis in the clause is related to mood. Specifically, it is related to the question-answer process in dialogue; and this determines that there are two kinds: 1. Yes/No ellipsis and 2. WH ellipsis (Halliday and Hasan, 1985: 297) in (DEDDY PERDANA BAKTI, 2017). Whole stretches of clausal components may also be omitted. Example "Is it supposed to be good or bad? " this sentence is a part of the script in the Hinglish Short movie what the researcher choose, that sentence showed the yes or no question, which omitted about Pria's and Charu's Marriage condition in seven years old.

Hinglish is a combination of Hindi and English language, what Hinglish is it? it is obviously a mixture of Hindi and English but is it the use of Hindi words and syntactical elements in English, how the Indian people use of English word and syntax in Hindi? According to Kothari and Snell (2011) in (NEMA \& CHAWLA, 2018) "Hinglish is a rootless phenomenon that can be only be used for the propagation of a global and (more important) branded culture" India with a population of 1.2 billion does not have a national language that causes mixed English and Hindi or Hinglish languages are increasingly being used.

Today many parents send their children to school with the use of English as the primary language. However, students who have graduated from school mostly use language that will not be understood in London or New York because it is a combination of English and Hindi. A number of parties said, this Hinglish language arises because of the unavailability of skilled English teachers and also because of the absence of a national language. After half a century of independence, English is still used as a primary language in colleges, national media, judiciary, and business. However, at the national government level, Hindi languages serve as the official language. Furthermore, the used of Hinglish language not apart from ellipsis, because in the Hinglish language of the Indians, in pronunciation there is a word deliberately/not lost from the original form.

The reason why the researcher interest to take this title because for the researcher using ellipsis in daily life to make the communication more effective, especially in written communication such us when ellipsis used in social media for chatting and for Hinglish language, why the researcher choose Hinglish language because of the researcher from Indonesian so the researcher wishes Indonesian people can used to with English seems like Hindia people who used many languages in their country, especially English language because as we know that the English Language is one of Lingua Franca which bridge of language to communicate with many people in the world.

Research Question :

1. What kind of Ellipsis is often used by Hinglish people in the short movie ?

2. How the Ellipsis can interpret the purpose of the speaker in that movie 


\section{METHOD}

This research design in this research is a qualitative research design with analysis of the dialogues from the movie. According to Sheman and Webb (1988) assume that qualitative research is concerned with meaning as they appear to, or are achieved by persons in lived social situations. Meanwhile, Bogdan and Biklen (1982) state that qualitative research is descriptive which the data is collected in the form of words or pictures rather than numbers in (Factors, Diabetic, \& Ulceration, 2003)

The Technique used in this research is collecting secondary data, Secondary data analysis is analysis of data that was collected by someone else for another primary purpose.The utilization of this existing data provides a viable option for researchers who may have limited time and resources. (Willey et al., 2017)

The procedure included: Finding the data, analyzing the data, a classification the data and make a result from the data. Analyzing the data by collecting, watching, classifying the data based on the research need, the method and the relevant concept from M.AK Halliday about written discourse in Ellipsis. the process of collecting data is done through the following steps:

1. Searching the video about the Hinglish short movie

2. Listening to the dialogue and write done the script from the movie

3. Choosing the Ellipsis used by the actor in the movie

4. Grouping the utterances in relation to the types of Ellipsis

5. Analyzing the data

6. Writing the report of the research

\section{RESULTS AND DISCUSSION}

\section{Results}

The data collection of this research taken from the Hinglish short movie with the title "Divorce" uploaded by Short Moviez Online on $8^{\text {th }}$ December 2011 presented by Twilight Entertainment Pvt. L.td 2011 -https://youtu.be/nswIUw2y8P4

The Data Of The Ellipsis used from "Divorce Short Movie

Data 1.

In the dialog from the Consultant: "so both of you had been married for seven years now"?There is ellipsis and that kind of ellipsis is nominal elipsis which means the common noun can be omitted by the function of the other elements which supported about ellipsis such us deictic, enumerative, epithet or classifier) but from the data above "both of you" there is used of nominal Non-specific deictic because "both of you" omitted about a couple of husband and wife (Pria and Charu ) wich who was talking with the speaker (consultant) and replace that phrase with "both of you".

And from the data above "so both of you" had been married for seven years now?" is can interpret about why a couple of marriage had been seven years living together want to take divorce, because "so both of you had been married for seven years now? Is the question like convincing them with the result which they take it (divorce) because the age of marriage in 
seven years level is included a long time and the consultant want to make that a couple of marriage (Pria and Charu) think twice about their result.

Data 2

In the dialogue from consultant : "Is it supposed to be good or bad? " there is ellipsis and in that sentence clausal ellipsis happened, because that sentence which bold is question-answer process dialogue sentence which question-answer is one of the characteristics from Clausal Ellipsis, Is it supposed to be good or bad is omitted about Charu and Pria's marriage in seven years old.

And from the data above "Is it supposed to be good or bad? " can interpret about how the condition and effect from their marriage (Cahru and Pria) in the seventh years are that in a good or bad condition? And how about the effect? Is that bring a good or bad sense.

\section{Data 3}

In the dialog from Charu "Damn...she does again" there are ellipsis and kind of ellipsis happened is verbal ellipsis because in that sentence has a verbal group clause "she does", "she does" omitted what Pria's doing in that time.

And from the data above "Damn...she does again" is interpret the hidden statement which show Pria whose Charu wife's who mocked Charu up about his behaviour that give a bad sense in their marriage in front of the other people except them self (Consultant) and Charu does not like about what Pria did in that time that showed when Pria said "He obviously mindset in a bad sense" (the dialog before Charu said "damn...she does again) Charu's expression getting mad directly and he said damn... she does again.

\section{Data 4}

In the dialog from Pria "You did" there are ellipsis and kind of ellipsis is verbal ellipsis happened because in that sentence has a verbal group in "did" in this dialog omitted about what Charu's did into Pria.

And from the data above "you did" is interpret the hidden statement which when they accused each other about who started mocked about their behavior in front of someone else and they do not want to resent each other, that situation make they debated that problem a lot.

\section{Data 5}

In the dialog from the consultant "So... Pria please tell me..." there is ellipsis and the kind of ellipsis happened in that dialog is verbal ellipsis because that dialog has a verbal group in telling me and that word omitted the next dialog which the consultant means.

And also from the data above "So... Pria please tell me..." show and interpret the consultant wan to know what happen in his client marriage (Pria and Charu) and what reason for them to take divorce, but in the first time when the consultant asking that question, Pria did not get the point yet. 


\section{Discussion}

Based on the data which research by the researcher in Hinglish Short Movie "Divorce", there found three types of Ellipsis exist and all of the data apropiate with the purpose of the reseacher which is the data used the ellipsis and and the ellipsis can interpert some ommision in the dialougue used in that movie.

Table 1. Percentage of Kinds of Ellipsis in the dialouge in "Divorce" movie

\begin{tabular}{cccc}
\hline No & Types Of Ellipsis & \multicolumn{1}{c}{ Sentences } & Total \\
\hline 1. & Nominal ellipsis & 1. "so both of you had been mariage for & 1 \\
& & & seven years now" ? \\
\hline 2. & Verbal & $\begin{array}{l}\text { 1. "Damn...she does again" } \\
\text { 2. "You did" }\end{array}$ & 3 \\
\hline 3. & Clausal & 1. "So... " Pria please tell me..." & 1 \\
\hline
\end{tabular}

Table 2. Percentage of Sentence and Interpretation Purpose from The Speaker in Divorce Short movie

\begin{tabular}{|c|c|c|}
\hline No. & Sentences & Interpetation Sentence \\
\hline 1. & $\begin{array}{l}\text { "so both of you had been mariage for } \\
\text { seven years now"? }\end{array}$ & $\begin{array}{l}\text { "so both of you" had been mariage for } \\
\text { seven years now?" is can interpret about } \\
\text { why a couple marriage had been seven years } \\
\text { life together want to take divorce, because } \\
\text { "so both of you had been mariage for seven } \\
\text { years now? Is the question like convincing } \\
\text { them with the result which they take it } \\
\text { (divorce), because age of marriage in seven } \\
\text { years level be included a long time and the } \\
\text { consultan want to make that a couple of } \\
\text { mariage (Pria and Charu) think twice about } \\
\text { their result. }\end{array}$ \\
\hline & "Damn...she does again" & $\begin{array}{l}\text { "Damn...she does again"can interpert about } \\
\text { how the condition and effect from their } \\
\text { marriage (Cahru and Pria) in the seventh } \\
\text { years is that in a good or bad condition? } \\
\text { And how about the effect? Is that bring a }\end{array}$ \\
\hline 3. & "You did" & $\begin{array}{l}\text { good or bad sense. } \\
\text { "You did " interpert the hiden statement } \\
\text { which when they accused each other about } \\
\text { who stareted mocked about their behaviour } \\
\text { infront of someone else and they do not } \\
\text { want to relented each other, that situation } \\
\text { make they debated that } \\
\text { problem a lot. }\end{array}$ \\
\hline
\end{tabular}




\begin{tabular}{ll}
\hline 4. "So... Pria please tell me..." & $\begin{array}{l}\text { "So... Pria please tell me..." show and } \\
\text { interpert the consultan wan to know what } \\
\text { happen in his client marriage (Pria and } \\
\text { Charu) and what reason for them to take } \\
\text { divorce, but in the first time when the } \\
\text { consultan asking that question, Pria did not } \\
\text { get the point yet. }\end{array}$ \\
\hline $\mathbf{5 . ~ " I s ~ i t ~ s u p p o s e d ~ t o ~ b e ~ g o o d ~ o r ~ b a d ~ ? " ~}$ & $\begin{array}{l}\text { "Is it supposed to be good or bad ? " } \\
\text { can interpert about how the condition and } \\
\text { effect from their marriage (Cahru and Pria) } \\
\text { in the seventh years is that in a good or bad } \\
\text { condition? And how about the effect? Is that } \\
\text { bring a good or bad sense. }\end{array}$ \\
\hline
\end{tabular}

From the data the researcher conclude the used of kind of ellipsis often is verbal ellipsis, and not every ommision of word which has an ellpsis success interpert the real meaning in each senteces.

\section{CONCLUSION}

Based on the results in previous point verbal ellipsis is a dominant kind of ellipsis used in "Divorce" Hinglish shirt movie, because the dialougues in that movie when the actor and the actris talking, they always ommision some of word which the verbal group to the previous verbal group, such us one of the dialogue use "Damn...she does again" there are ellipsis and kind of ellipsis happened is verbal ellipsis because in that sentence has a verbal group clause "she does", "she does" omitted what Pria's doing in that time. And other kinds of ellipsis which has use in this movie are Nominal ellipsis and Clausal ellipsis. In this research the researcher conclude ellipsis can be use if between the sepaker and listener understand with what they are talking about (there are conection in communication) because sometimes doing ommsion some of word in the sentence make a miss communication .

\section{ACKNOWLEDGMENTS}

Alhamdulillah all gratitude to Allah S.W.T who gave His blessing to researchers, so researchers can finish this article with good health condition. Researchers would like to say the biggest thank you for researchers' article supervisors who always gave researchers support when conducting this research. Also, researchers would like to say thank you to IKIP Siliwangi Bandung which gave us opportunity to publish this article. Also for blind reviewer who were reviews

\section{REFERENCES}

Deddy Perdana Bakti. (2017). The Analysis Of Elliptical Construction In The Transporter Refueled Movie: Discourse Approach. (6), 67-72.

Factors, A. R., Diabetic, F. O. R., \& Ulceration, F. (2003). Chapter Iii. 31-36.

Lewis, C. S. (2017). Concept Of Film. The Analaysis Of Ellipsis In The Chronicles Of Narnia Film By Clive Staples Lewis Herlina Management And Computer Science College (Stmik) Mura Lubuklinggau, Indonesia Herlina6102@Gmail.Com, 31-38.

Nema, N., \& Chawla, J. K. (2018). The Dialectics Of Hinglish: A Perspective. Applied 
Linguistics Papers, 2/2018(25), 37-51.

Https://Doi.Org/10.32612/Uw.25449354.2018.2.Pp.37-51

Sholeh, A. (2014). A Discourse Analysis Of Cohesion In "Romeo And Juliet" Movie. A Discourse Analysis Of Cohesion In "Romeo And Juliet" Movie, (09320016), 561-565.

Tajeddin, Z., \& Rahimi, A. (2017). A Conversation Analysis Of Ellipsis And Substitution In Global Business English Textbooks. 1-14.

Willey, J. Z., Moon, Y. P., Kulick, E. R., Cheung, Y. K., Wright, C. B., Sacco, R. L., \& Elkind, M. S. V. (2017). Physical Inactivity Predicts Slow Gait Speed In An Elderly Multi-Ethnic Cohort Study: The Northern Manhattan Study. Neuroepidemiology, 49(1-2), 24-30. Https://Doi.Org/10.1159/000479695 